\title{
Soybean Seed Coats: A Source of Ingredients for Potential Human Health Benefits-A Review of the Literature
}

\author{
Corliss A. O’Bryan ${ }^{1,3}$, Kalpana Kushwaha ${ }^{1}$, Dinesh Babu ${ }^{1, \S}$, Philip G. Crandall ${ }^{1,3}$, Mike L. Davis ${ }^{1}$, \\ Pengyin Chen ${ }^{2}$, Sun-Ok Lee ${ }^{1} \&$ Steven C. Ricke ${ }^{1,3}$ \\ ${ }^{1}$ Department of Food Science, University of Arkansas, Fayetteville, AR 72704, USA \\ ${ }^{2}$ Crop, Soil and Environmental Sciences, University of Arkansas, Fayetteville, AR 72701, USA \\ ${ }^{3}$ Center for Food Safety, University of Arkansas, Fayetteville, AR 72704, USA \\ $\S$ Present address: Food Safety Toxicology, College of Pharmacy, University of Louisiana at Monroe, Monroe, \\ LA 71209 , USA \\ Correspondence: Philip G. Crandall, Department of Food Science, University of Arkansas, Fayetteville, AR, \\ 72704, USA. Tel: 1-479-575-7686. E-mail: crandal@uark.edu
}

Received: August 12, 2014 Accepted: September 10, 2014 Online Published: November 11, 2014

doi:10.5539/jfr.v3n6p188 URL: http://dx.doi.org/10.5539/jfr.v3n6p188

\begin{abstract}
Soybean seed coats are an underutilized byproduct from the commercial crushing of soybeans to make soymeal and soy oil. These seed coats constitute 7 to $10 \%$ of the weight of a bushel of soybeans so they provide a substantial opportunity to add value to each bushel. Overall, the United States produces approximately 6 million metric tons of seed coats each year. Biologically active compounds contained in soybean seed coats have been shown to prevent and or reduce macular degeneration, obesity, cancer, and many other debilitating diseases. For example the seed coats of YJ-100 black soybeans contain more than $20 \mathrm{mg} / \mathrm{g}$ of anthocyanins, the highest concentration of anthocyanins of all plants materials including other row crops. The purpose of this paper is to examine the chemical content of soybean seed coats, highlight opportunities to add value and discuss the potential health benefits of these chemicals.
\end{abstract}

Keywords: anthocyanins, bowman birk inhibitor, iron, soybean seedcoats

\section{Introduction}

\subsection{History of Soybeans}

Economically, soybeans are the most important bean in the world and have been a major part of the diet in many Asian countries for more than 5,000 years. Soybean and soy products represent one of the richest and most economical sources of protein (Codina, Arduso, Lockney, Crisci, \& Medina, 2003). In the early 1900s soybeans were grown mainly in China, Indonesia, Japan, and Korea (Burtis, 1950). World War II disrupted the flow of soybeans from Manchuria to Europe, and after the war soy exports never resumed (Shurtleff \& Aoyagi, 2007). During this same war-time period the U.S. needed domestic sources of fats, oils, and animal feed meal and consequently increased soybean production, passing both Manchuria and China in one year to become the world's leading soybean producing country (Shurtleff \& Aoyagi, 2007). Global soybean production for 2013-2014 is projected at 281.7 million tons (Agricultural Marketing Service, 2013). Soybeans are used primarily as an oil seed but also serve as a feedstock for livestock and aquaculture, as well as being a good source of protein for the human diet. Soy oil has recently become important as a biofuel feedstock (Masuda \& Goldsmith, 2009). Soy is also used as soy flour and soy oil in baking, bread-making, and processed foods including textured vegetable protein and a range of imitation meat products (Roccisano \& Henneberg, 2012).

Consumption of soybeans as a human food is a very small part of the overall soybean production, only $6 \%$, but it is still significant in terms of volume and value (Golbitz, 2010). Reported values of soy food consumption are difficult to find, especially for Western populations, but there are estimates of the amounts of soy isoflavones. In parts of Europe consumption of isoflavones from soy has been estimated to be less than $1 \mathrm{mg} /$ day (Keinan Boker et al., 2002; Van Erp-Baart et al., 2003), whereas for the U.S. it is estimated to be between 0.5 and $3 \mathrm{mg} / \mathrm{day}$ (Horn-Ross et al., 2000a, 2000b; de Kleijn et al., 2001). On the other hand it has been reported that in some Asian populations consumption may be as much as 20 to $80 \mathrm{mg}$ /day of genistein from traditional soy foods. 
Sources of isoflavones also differ between Japanese and Western populations. Fermented soy foods such as miso and natto account for about $40 \%$ of total isoflavone intake in Japan whereas in Western populations, a large portion of total isoflavone consumption is derived from soy protein and soy flour added as functional food ingredients to a wide variety of foods (de Kleijn et al., 2001).

Soybeans contain $35-40 \%$ protein on a dry weight basis (Torres, Torre-Villalvazo, \& Tovar, 2006) with all of the essential amino acids except for methionine and tryptophan (Zarkadas, Yu, \& Voldeng, 1993) which makes soy products almost equivalent in the quality of the protein to animal sources but with far less saturated fat and zero cholesterol (Young, 1991). Soybean contains about 30-32\% of soluble and insoluble carbohydrates. Soybeans also contain a number of minor constituents including phospholipids, vitamins and minerals, trypsin inhibitors, phytic acid, saponins and isoftavones, some of which are thought to have beneficial biological effects in the diet, such as lowering blood cholesterol or preventing cancer (Table 1). The content of isoflavones varies greatly in different soy parts with the germ having the highest level of total isoflavones, followed by cotyledon and seed coat (Yue et al., 2010). Several reviews of isoflavone effects on human health have been written including Isanga and Zhang (2008), Omoni and Aluko (2008), Dinsdale and Ward (2010), and Kushwaha et al. (2014).

Phenolic compunds also naturally occur in soybeans, including flavonoids, tannins and lignin precursors (Malenčić, Popović, \& Miladinović). Many researchers assert that phenolics may act as antioxidants, reducing the risk from coronary heart disease, and may also play an anticancer role (Grassmann, Hippeli, \& Elstner, 2002; Blokhina, Virolainen, \& Fagerstedt, 2003). Xu and Chang (2008) found that the seed coats of soybeans had higher total phenolic indexes and antioxidant activities than whole or dehulled soybeans. However, they also discovered that assay methods affected the amount of antioxidant capacity attribuatable to seed coats or dehulled beans. The 2-diphenyl-1-picryhydrazyl (DPPH) and ferric reducing antioxidant power (FRAP) methods determined that the seed coat contributed $90 \%$ of the total antioxidant capacity, but when measured with the oxygen radical absorbance capacity (ORAC) method, the seed coat and dehulled portion contributed about the same amount to the total antioxidant capacity (Xu \& Chang, 2008). While these antioxidant capacities measured by these assays are impressive, the extent that these phenolic compunds contribute to clinical outcomes of human disease processes is still being debated (Habauzit \& Morand, 2011).

Saponins are detergent like compounds found in many plant species, including the soybean. Saponins from soy have been reported to have several health improving functions incuding functioning as antioxidants (Yoshikoshi, Yoshiki, Okubo, Seto, \& Sasaki, 1996; Ishii \& Tanizawa, 2006), lowering of cholesterol (Lee, Simons, Murphy $\&$ Hendrich, 2005), protecting against kidney and liver disease (Kinjo, Imagire, Udayama, Arao, \& Nohara, 1998; Philbrick, Bureau, Collins, \& Holub, 2003), and shrinking or preventing cancerous tumors (Kerwin, 2004). The soy hypocotyl has the greatest concentration of saponins, and there are none present in the seed coats (Anderson \& Wolf, 1995; Jin, Yang, Su, \& Ren2006).

For every ton of soybeans processed approximately $8 \%$ of the total mass is discarded as soybean seed coats, also called hulls (Sessa, 2004). At present, some soy hulls are used to produce feed for cattle and other animals, but large amounts of soy hulls are left to waste (Sessa, 2004).

Table 1. Major nutrient content of soybeans (per $100 \mathrm{~g}$ )

\begin{tabular}{lll}
\hline Nutrients & Amount & Reference \\
\hline Protein & $40-50 \mathrm{~g}$ & Wolf, 1970 \\
Fat (total lipid) & $20 \mathrm{~g}$ & Garcia, 1997 \\
Carbohydrates & $11 \mathrm{~g}$ & Openshaw \& Hadley, 1979 \\
Fiber & $9.3 \mathrm{~g}$ & Wolf, 1970 \\
Trypsin inhibitors & $16.7-27.2 \mathrm{mg} / \mathrm{g}$ & Anderson \& Wolf, 1995 \\
Phytic acid & $1.0-2.3 \mathrm{~g} / 100 \mathrm{~g}$ & Lolas, Palamidis, \& Markakis, \\
& & $1976 ;$ Raboy \& Dickinson, 1984 \\
Saponins & $0.09-0.53 \mathrm{~g} / 100 \mathrm{~g}$ & Anderson \& Wolf, 1995 \\
Isoflavones & $1.1-4.2 \mathrm{mg} / \mathrm{g}$ & Anderson \& Wolf, 1995 \\
\hline
\end{tabular}




\subsection{Soybean Seed Coat Composition}

The seed coat of the mature soybean has been well characterized, and contains features in common with the majority of the legumes: an epidermal layer of palisade cells, or macrosclereids, a sub-epidermal layer of hourglass cells, or osteosclereids, a few layers of parenchyma, and an aleurone layer (Miller, Bowman, Gizen, \& Miki, 1999). These features give the seed coat mechanical strength and some degree of impermeability to water and/or gases in order to regulate the metabolism, growth, and development of the inner tissues and organs of the seed (Murray, 1979); it has been hypothesized that the seed coats may determine seed size (Corner, 1951; Stafford, 1978). Soy hulls contain much less protein than the whole soybean, but are much higher in fiber (Table 2). Certain compounds that may have a health benefit for humans, such as antioxidants and anthocyanins, are in greater abundance in the seed coat than in the interior of the seed (Xu \& Chang, 2008). As far back as 1992 it had been determined that inclusion of dietary fiber from soybean seed coats lowered the levels of total lipids, cholesterol and glycerides (Uberoi, Vadhera, \& Soni, 1992). According to Murray-Kolb, Welch, Theil, and Beard (2003), soybean seed coats are a good source of iron partially due to the low phytate levels, since phytate is known to reduce the bioavailability of iron in foods. Seed coats doubtless contain other minerals but no mineral deficiency in humans is as widespread as that of iron, and we will therefore restrict our discussion to this single mineral. Gizjen, van Huystee, and Buzzell (1993) reported differences in levels of peroxidase are different in the hulls of different soybean cultivars. Alvarez, Krzyzanowski, Mandarino, and França-Neto (1997) indicated that lignin levels vary amongst various types of soybean seed coats. Xu and Chang (2008) suggested that almost three-quarters, $73.4 \%$, of the phenolic antioxidant compounds are found in the seed coat part of the soybean. In a study by Sessa and Wolfe (2001), it was reported that soybean seed coats may provide a source of trypsin inhibitor the Bowman-Burk Inhibitor (BBI), which could be a potential anticancer agent. Soybean seed coats do not contain appreciable amounts of phytic acid, saponins or isoflavones (Table 2).

Table 2. Major nutrient content of soybean seed coats (hulls) per $100 \mathrm{~g}$

\begin{tabular}{lll}
\hline Nutrients & Amount & Reference \\
\hline Protein & $9 \mathrm{~g}$ & Liu, 1997 \\
Fat (total lipid) & $21.0 \mathrm{~g}$ & Liu, 1997 \\
Carbohydrates & $21 \mathrm{~g}$ & Liu, 1997 \\
Fiber & $65 \mathrm{~g}$ & Cole et al., 1999 \\
Isoflavones & $90-600 \mu \mathrm{g}$ & Phommalth et al., 2008 \\
Trypsin inhibitors & $44 \mathrm{mg} / \mathrm{g}$ & Sessa \& Wolf, 2001 \\
Phytic acid & $0.12-0.50 \mathrm{~g} / 100 \mathrm{~g}$ & Lehrfeld, 1989; Sutardi \& Buckle, 1985 \\
Saponins & 0 & Anderson \& Wolf, 1995 \\
Isoflavones & $0.11-0.20 \mathrm{mg} / \mathrm{g}$ & Eldridge \& Kwolek, 1983 \\
\hline
\end{tabular}

Soybean seed coats exist in a range of colors from black, brown, green, blue, yellow to mottled. Commercially grown soybean (Glycine max) varieties have yellow seeds; however, some soybean varieties accumulate anthocyanins within the epidermal layer of the seed coat leading to the range in colors (Todd \& Vodkin, 1993). Two unlinked loci control the color of seed coats; one locus controls where anthocyanins are produced and results in 4 unique phenotypes: complete absence of seed coat pigment, pigment limited to the narrow hilum area where seed and pod are attached, pigment in a saddle-shaped region over two-thirds of the seed coat, or a completely pigmented seed coat (Lindstrom \& Vodkin, 1991). Colored seed coats contain anthocyanins as well as other chemicals of potential interest for human health. The remainder of this review will detail some of the most abundant chemicals found in soybean seed coat and explore the potential impact on human health.

\section{Selected Valuable Components of Soybean Seed Coats}

\subsection{Iron}

Iron deficiency anemia (IDA) is the most common and widespread nutritional disorder in the world, and is also the only deficiency that is present in industrialized countries as well as in developing ones (Shaw \& Friedman, 2011). Infants are the most susceptible group due to their high demand for iron during rapid growth coupled with a diet typically low in bioavailable iron even when breast-fed past 6 months of age (INACG, 1998). After 6 
months of age, dietary requirements for iron increase markedly, leading to iron deficiency in late infancy and into the second year of life (Aggett, Barclay, \& Whitley, 1989). If the deficiency progresses into IDA there may be delayed mental and motor development (Booth \& Aukett, 1997) and the consequences of IDA may be irreversible (Aggett et al., 2002).

Soybean seed coats were identified in the early 1980 s as being a rich source of dietary iron (Levine, Weaver, \& Kirleis, 1982; Weaver, Nelson, \& Elliott, 1984). While the iron in hulls is readily assimilated by humans, soybean meal has very poor iron bioavailability (Welch \& Van Campen, 1975; Jacob, Sandstead, Klevay, \& Johnson, 1980; Lynch, Beard, Dassenko, \& Cook, 1984; Johnson, Berry, \& Weaver, 1985; Lykken, Mahalko, Nielsen, \& Dintzis, 1987; Beard et al., 1988). Martino et al. (2011) studied the chemical composition and iron bioavailability to rats of soybean flour with and without hulls made from a new cultivar of soybean. Soybean hull flour contained 37\% more total dietary fiber and a higher content of iron than the hull-less soybean flour. Animals fed soybean flour with hulls presented hemoglobin gains similar to those of the control diet group. Heat-treated soybean hull flour had a high content of iron and low content of phytate, which favors iron bioavailability. Thus soybean hulls may have potential as a source of iron fortification in baked products.

\subsection{Bowman Birk Inhibitor}

The Bowman-Birk inhibitor (BBI), initially identified in the 1940s (Bowman, 1944, 1946) and later purified by Birk (1961) is the major protease inhibitor present in soybean seed coats. Soybean BBI is a known cancer chemopreventative and anticarcinogenic agent (Sessa \& Wolf, 2001). The potential for using BBI as a therapeutic agent has been studied for many years; early animal studies demonstrated that BBI prevents the development of malignancies in different animal tumor model systems (Kennedy, Beazer-Barclay, Kinzler, \& Newbern, 1996). A soybean preparation enriched in BBI received drug status by the U.S. FDA and was evaluated in human clinical trials for treatment of benign prostatic hyperplasia or precancerous conditions, such as oral leukoplakia and ulcerative colitis (Table 3).

Table 3. Clinical trials utilizing a protein extract of soybean enriched in Bowman-Birk inhibitors

\begin{tabular}{|c|c|c|c|c|}
\hline Disease & Trial type & Exp. design & Results & Reference \\
\hline $\begin{array}{l}\text { Benign } \\
\text { prostatic } \\
\text { hyperplasia }\end{array}$ & Phase I & $\begin{array}{l}\text { Duration: } 6 \\
\text { months } \\
19 \text { patients. } \\
\text { Daily dose } \\
\text { up to } 800 \mathrm{CIU}^{\mathrm{a}}\end{array}$ & $\begin{array}{l}\text { Significant decrease (up to } 43 \% \text { ) in } \\
\text { PSA }^{\mathrm{b}} \text { levels after treatment. Decrease } \\
\text { of prostate volume in patients. No } \\
\text { dose-limiting toxicity }\end{array}$ & $\begin{array}{l}\text { Malkowicz et } \\
\text { al., } 2001\end{array}$ \\
\hline $\begin{array}{l}\text { Oral } \\
\text { leukoplakia }\end{array}$ & Phase I & $\begin{array}{lr}\text { Duration: } & 1 \\
\text { month. } & 24 \\
\text { patients. Single } \\
\text { daily dose } & 800 \\
\text { CIU }\end{array}$ & $\begin{array}{l}\text { BBI well tolerated, no clinical } \\
\text { evidence of toxicity, no adverse } \\
\text { reaction }\end{array}$ & $\begin{array}{l}\text { Armstrong et } \\
\text { al., } 2000 \mathrm{a}\end{array}$ \\
\hline $\begin{array}{l}\text { Oral } \\
\text { leukoplakia }\end{array}$ & Phase II & $\begin{array}{l}\text { Duration: } 1 \\
\text { month. } 32 \\
\text { patients. Twice } \\
\text { daily up to } \\
1066 \text { CIU }\end{array}$ & $\begin{array}{l}31 \% \text { had clinical response, lesion area } \\
\text { decreased. Dose dependent. No } \\
\text { toxicity observed }\end{array}$ & $\begin{array}{l}\text { Armstrong et } \\
\text { al., } 2000 \mathrm{~b}\end{array}$ \\
\hline $\begin{array}{l}\text { Oral } \\
\text { leukoplakia }\end{array}$ & $\begin{array}{l}\text { Double blind, } \\
\text { randomized, placebo } \\
\text { controlled phase IIb }\end{array}$ & $\begin{array}{l}148 \text { patients. } \\
\text { Daily dose } 600 \\
\text { CIU }\end{array}$ & $\begin{array}{l}\text { No statistically significant difference } \\
\text { between placebo and treatment } \\
\text { groups }\end{array}$ & $\begin{array}{l}\text { Armstrong et } \\
\text { al., } 2013\end{array}$ \\
\hline $\begin{array}{l}\text { Ulcerative } \\
\text { colitis }\end{array}$ & $\begin{array}{l}\text { Randomized, double } \\
\text { blind, } \\
\text { placebo-controlled }\end{array}$ & $\begin{array}{l}12 \text { weeks of } \\
\text { therapy. } 28 \\
\text { patients. Daily } \\
\text { dose } 800 \text { CIU }\end{array}$ & $\begin{array}{l}\text { Index scores of patients receiving } \\
\text { BBI decreased more than those of } \\
\text { patients receiving placebo. Beneficial } \\
\text { trends were observed in the rates of } \\
\text { remission and clinical response. No } \\
\text { severe adverse events were observed. }\end{array}$ & $\begin{array}{l}\text { Lichtenstein } \\
\text { et al., } 2008\end{array}$ \\
\hline
\end{tabular}

${ }^{\mathrm{a}} \mathrm{CIU}$ : chymotrypsin inhibitory units. ${ }^{\mathrm{b}} \mathrm{PSA}$ : prostate specific antigen 
Malkowicz et al. (2001) observed a significant decrease in prostate specific antigen levels as well as a decrease of prostate volume after treatment with soy BBI. In early trials results for oral leukoplakia were promising, but in a phase II trial there was no difference between the placebo and BBI groups (Armstrong et al., 2000a, 2000b, 2013). Amigo-Benavent, Nitride, Bravo, Ferranti, and del Castillo (2013) evaluated the feasibility of soybean BBI as a natural functional food ingredient added to orange juice. Samples of freshly squeezed orange juice and two orange juice model systems with and without BBI were prepared and processed mimicking pasteurization and sterilization industrial conditions, and stored at $4^{\circ} \mathrm{C}$ for two months. The samples were digested in vitro under oral-gastrointestinal physiological conditions. Results indicated that the activity of BBI survived thermal processing, storage and digestion processes. Furthermore, BBI has been proposed as an oral delivery treatment for multiple sclerosis or other autoimmune disorders (Gran et al., 2006; Safavi \& Rostami, 2012) and its biotechnological potential as a molecular building block is still being explored (Losso, Munene, Bansode, \& Bawadi, 2004; Muricken \& Gowda, 2011). Thus, soybean seed coats may provide a new, inexpensive source of BBI concentrate for use as a potential anticancer agent.

\subsection{Anthocyanins}

Anthocyanins are intensely colored, water-soluble pigments that can be obtained from various fruits, vegetables, roots, tubers, bulbs, legumes, and cereals; over 300 structurally distinct anthocyanins have been identified in nature (Mazza \& Miniati, 1993; Petri, Krawczyk, \& Kery, 1997; Bridle \& Timberlake, 1997; Renault et al., 1997). Several anthocyanins have been identified in soybean seed coats (Table 4). Anthocyanins are also known to have pharmaceutical effects (Mazza \& Miniati, 1993; Fiorini, 1995; Petri et al., 1997) and have been used in the treatment of various circulatory disorders (Bettini, Fiori, Martino, Mayellaro, \& Ton, 1985) and inflammatory disease (Vincieri, 1992). Waterhouse (1995) reported that the antioxidant properties of anthocyanins may reduce the risk of coronary heart disease. Soybeans have various seed coat colors including yellow, green, brown, or black, which are due to anthocyanins, chlorophyll, and various combinations of breakdown products of these pigments in the seed coat (Todd \& Vodkin, 1993; Chung, 1998). Several authors reported that seed coats from black soybeans contain the greatest levels of anthocyanins of all pigmented soybeans (Choung et al., 2001; Zhang et al., 2011).

Damage to the heart muscle caused by the return of blood flow to tissue that was deprived of oxygen (reperfusion injury) is mediated by a pro-inflammatory cytokine, tumor necrosis factor-alpha (TNF- $\alpha$; Shames et al., 2002). Kim et al. (2006) demonstrated that anthocyanins isolated from black soybean seed coat inhibited TNF- $\alpha$ induced molecules and protected against reperfusion injury in rats.

Kwon et al. (2007) evaluated the effects of anthocyanins extracted from black soybean seed coats on body weight, adipose tissue weight, and serum lipids in rats fed a high fat diet with or without anthocyanins from black soybean seed coats. Weight gain was significantly less in the rats on the high fat diet with black soybean anthocyanins compared with the rats on the high fat diet alone and lipid profiles were also improved. Kanamoto et al. (2011) further determined that extract of black soybean seed coats improved glucose tolerance and lessened obesity by up-regulating uncoupling proteins down-regulating inflammatory cytokines in mice fed a control or high-fat diet containing extract. They concluded that extract of black soybean seed coats could be beneficial for the prevention of obesity and diabetes by enhancing energy expenditure and suppressing inflammation.

Colorectal cancer is one of the most common types of cancer worldwide; the results of some epidemiological and experimental studies have suggested that soy intake decreases the risk of colorectal cancer, although other researchers have said that there is no conclusive evidence showing that soy reduces the risk of cancer (Messina \& Barnes, 1991). Kim, Kim, Yoo, Choung and Sung (2008) studied the anti-inflammatory and antiproliferative activities of anthocyanidins and anthocyanin-rich black soybean seed coats in HT-29 human colon adenocarcinoma cells and carcinogen-treated F344 rats and found that anthocyanidins are possible anti-inflammatory agents, although in their experiment they did not observe anti-tumor effects.

Ultraviolet radiation (UV) especially UVB plays a major role in the development of human skin cancer (Ley, Applegate, Fry, \& Sanchez, 1991; Matsui \& deLeo, 1995). Cylooxygenase-2 (COX-2) production is significantly increased by UVB exposure and is often used as an early marker for potential skin tumor formation (Athar et al., 2001). Tsoyi et al. (2008) determined that anthocyanins isolated from black soybean seed coats inhibited COX-2 production in a human keratinocyte cell line. They also found that topical application of anthocyanins prior to UVB irradiation of hairless mice also inhibited induction of COX-2, and they therefore suggested that anthocyanins from the seed coat of black soybeans can be used to modulate UVB-induced inflammation and potentially act to reduce the risk of skin cancer.

Hyperglycemia, as well as abnormal lipid and antioxidant profiles, are some of the most usual complications in 
diabetes mellitus. Nizamutdinova et al. (2009) investigated the anti-diabetic and anti-oxidative effects of anthocyanins from black soybean seed coats in rats with induced diabetes. Anthocyanins significantly decreased glucose levels and improved heart function and also decreased the triglyceride levels in blood serum that had been raised by the diabetes inducing drug. Interestingly, they found that the observed effects of the anthocyanins were superior to those of glibenclamide, a drug commonly used to treat type 2 diabetes in humans.

Paik et al. (2012) examined the effect of anthocyanins extracted from the seed coat of black soybean on an animal model of retinal degeneration (RD), a leading cause of photoreceptor cell death that results in blindness. Anthocyanins were given daily by mouth for 1,2 or 4 weeks in rats with induced RD. In control rats with induced retinal damage, electroretinographic (ERG) recordings showed a gradual significant time-dependent reduction in both a- and b-wave amplitudes compared with those of normal animals. In the RD rats given anthocyanins for long-term treatment, 4 weeks, ERG responses were significantly increased compared with untreated $\mathrm{RD}$ rats; however, in the $\mathrm{RD}$ rats given anthocyanins for 1 and 2 weeks, the increase in ERG responses was not significant.

Table 4. Anthocyanins isolated from soybean seed coats

\begin{tabular}{ll}
\hline Anthocyanin & Reference \\
\hline delphinidin-3-glucoside & Choung et al., 2001 \\
cyanidin-3-glucoside & Choung et al., 2001 \\
petunidin-3-glucoside & Choung et al., 2001 \\
pelargonidin-3-glucoside & Lee et al., 2009 \\
cyanidin & Lee et al., 2009 \\
catechin-cyanidin-3-glucoside & Lee et al., 2009 \\
delphinidin-3-galactoside & Lee et al., 2009 \\
cyanidin-3-galactoside & Lee et al., 2009 \\
peonidin-3-glucoside & Lee et al., 2009 \\
malvidin-3-glucoside & Zhang et al. 2011 \\
\hline
\end{tabular}

\subsection{Peroxidase}

The enzyme peroxidase contained within the seed coats of soybeans has a potentially high commercial value. It has been known since the 1960s that soybean seed coats contain various peroxidases but it was not until the late 1990s that peroxidase was able to be measured and extracted from soybean hulls (Vierling \& Wilcox, 1996). Peroxidases are used in a wide variety of applications including biocatalysis, diagnostic testing, biosensors, recombinant protein expression, transgenics, bioinformatics, protein engineering and even therapeutics (Ryan, Carolan, \& O'Fagain, 2006). Soybean peroxidase (SBP) is more stable, acts on a broader range of compounds, and has higher oxidation power than other enzymes (Wright \& Nicell, 1999). Horseradish peroxidases are currently the most used and studied peroxidases, but the supply of the horseradish is limited and horseradish peroxidases are very unstable under high temperature (Kamal \& Behere, 2002). Horseradish peroxidase requires enhancers when used in ELISA systems whereas SBP can be used in a very simple detection system using only luminol and hydrogen peroxide, without the need of enhancers (Alpeeva \& Sakharov, 2005).

\subsection{Fiber}

The beneficial effects of increased fiber consumption are well known and have been thought by many to result from chemical and/or physical properties of the intact fiber such as water-holding capacity or adsorption of bile acids (Jenkins, 1988). However, it became obvious to early researchers that many of the beneficial effects of fiber are mediated by short-chain fatty acids (SCFAs) including acetate, propionate, and butyrate, which are produced during anaerobic fermentation in the colon (Titgemeyer, Bourquin, Fahey, \& Garleb, 1991). Titgemeyer et al. (1991) assessed production of SCFAs from various fiber sources with in vitro incubations with human fecal bacteria as inoculum. Total SCFA production from soy fiber ranked second only to citrus pectin and well ahead of sugar beet fiber, pea fiber and oat fiber. Fermentation of soy fiber also led to higher proportions of propionate and butyrate than did fermentation of other substrates. Propionate has been shown to lower glucose-induced insulin secretion in isolated pancreatic islet cells of rats (Ximenes, Hirata, Rocha, Curi, \& 
Carpinelli, 2007). It is also reported that propionate has anti-proliferative effects on colon cancer (Scheppach, Bartram, \& Richter, 1995; Jan et al., 2002) and is related to weight control and eating behavior (Oba \& Allen, 2003; Zhou et al, 2008).

Clostridium difficile colitis is a disabling complication in critically ill patients who are receiving broad-spectrum antibiotics and are on liquid diets. Frankel et al. (1994) used a hamster model to determine whether the addition of soy fiber to a liquid diet prevented or lessened the effects of $C$. difficile. Syrian hamsters were given either clindamycin or $C$. difficile (to produce ileocecitis), or equivalent volumes of saline, then fed either a routine liquid diet or the same diet with $1.4 \%$ soy fiber for 10 days. The addition of soy fiber recued toxin production and liquidity of stooles compared to the control, as well as increasing survival by $34 \%$. It was also determined that fiber supplementation was able to prolong survival in this model due in part to a delay in onset of $C$. difficile infection, and in part to improved water absorption in the colon.

\section{Conclusions}

There is an increasing interest in maximizing the utility of waste streams from processed fruits and vegetables in order to boost economic efficiency and reduce waste. Soybean seed coats, also known as hulls, represent a large waste stream in the United States and other countries. Eating foods made with soy has long been associated with a lowered risk of heart disease and cancer, among others. These health benefits have often been studied in relation to a particular soy component, such as isoflavones and anthocyanins. Isoflavones are not found in the seed coats, but a large number of other beneficial chemicals such as the anthocyanins, Bowman Birk Inhibitor, and dietary fiber are present in the seed coats. At the present time the seed coats removed from soybeans in the crushing plants where meal and oil are produced are either put back into the meal or sold for direct use as animal feed. While hulls are primarily seen as a waste by-product, there is potentially high commercial value associated with the enzymes and other chemicals contained within the seed coats

Additionally, studies indicate that soybeans with black, brown, green, and yellow seed coats differ in their antioxidant properties, flavonoid levels, total phenolic contents, and proanthocyanidin content. For instance, black soybeans have been shown to have greater inhibitory effect against lipid peroxidation in human LDL than yellow ones. This suggests the possibility of developing novel soybean lines with a selected seed coat color to be used as bioactive ingredients in functional foods targeting different health problems.

\section{Acknowledgments}

The preparation of this manuscript was financed in part by a grant from the Arkansas Soybean Board.

\section{References}

Aggett, P. J., Agostoni, C., Axelsson, I., Bresson, J. L., Goulet, O., Hernell, O., ... Weaver, L. T. (2002). Iron metabolism and requirements in early childhood: do we know enough? A commentary by the ESPGHAN Committee on Nutrition. Journal of Pediatric Gastroenterology and Nutrition, 34, 337-345. http://dx.doi.org/10.1097/00005176-200204000-00003

Aggett, P. J., Barclay, S., \& Whitley, J. E. (1989). Iron for the suckling. Acta Paediatrica Scandinavica Supplement, 361, 96-102.

Agricultural Marketing Service. (2013). World agricultural supply and demand estimates. Retrieved from http://www.usda.gov/oce/commodity/wasde/latest.pdf

Alpeeva, I. S., \& Sakharov, I. Y. (2005). Soybean peroxidase-catalyzed oxidation of luminol by hydrogen peroxide. Journal of Agriculture and Food Chemistry, 53, 5784-5788. http://dx.doi.org/10.1021/jf0506075

Alvarez, J. C., Krzyzanowski, F. C., Mandarino, J. M. G., \& França-Neto, J. B. (1997). Relationship between soybean seed coat lignin content and resistance to mechanical damage. Seed Science and Technology, 25, 209-214.

Amigo-Benavent, M., Nitride, C., Bravo, L., Ferranti, P., \& del Castillo, M. D. (2013). Stability and bioactivity of a Bowman-Birk inhibitor in orange juice during processing and storage. Food and Function, 4, 1051-1060. http://dx.doi.org/10.1039/c3fo30354c

Anderson, R. L., \& Wolf, W. J. (1995). Compositional changes in trypsin inhibitors, phytic acid, saponins and isoflavones related to soybean processing. The Journal of Nutrition, 125, S581-S588.

Armstrong, W. B., Kennedy, A. R., Wan, X. S., Atiba, J., McLaren, C. E., \& Meyskens, F. L. (2000a). Single-dose administration of Bowman-Birk Inhibitor concentrate in patients with oral leukoplakia. Cancer Epidemiology, Biomarkers \& Prevention, 9, 43-47. 
Armstrong, W. B., Kennedy, A. R., Wan, X. S., Taylor, T. H., Nguyen, Q. A., Jensen, J., \& Thompson, W. (2000b). Clinical modulation of oral leukoplakia and protease activity by Bowman-Birk Inhibitor concentrate in a Phase IIa chemoprevention trial. Clinical Cancer Research, 6, 4684-4691.

Armstrong, W. B., Taylor, T. H., Kennedy, A. R., Melrose, R. J., Messadi, D. V., Gu, M., ... Meyskens, F. L. (2013). Bowman Birk inhibitor concentrate and oral leukoplakia: a randomized Phase IIb trial. Cancer Prevention Research, 6, 410-418. http://dx.doi.org/10.1158/1940-6207.CAPR-13-0004

Athar, M., An, K. P., Morel, K. D., Kim, A. L., Aszterbaum, M., Longley, J., \& Bickers, D. R. (2001). Ultraviolet B (UVB)-induced cox-2 expression in murine skin: An immunohistochemical study Biochemical and Biophysical Research Communications, 280, 1042-1047. http://dx.doi.org/10.1006/bbrc.2000.4201

Beard, J., Weaver, C. M., Lynch, S., Johnson, C. D., Dassenko, S., \& Cook, J. D. (1988). The effect of soybean phosphate and phytate content on iron bioavailability. Nutrition Research, 8, 345-352. http://dx.doi.org/10.1016/S0271-5317(88)80029-0

Bettini, V., Fiori, A., Martino, R., Mayellaro, R., \& Ton, P. (1985). Study of the mechanism whereby anthocyanosides potentiate the effect of catecholamines on coronary vessels. Fitoterapia, 54, 67-72.

Birk, Y. (1961). Purification and some properties of a highly active inhibitor of trypsin and $\alpha$-chymotrypsin from soybeans Biochimica et Biophysica Acta, 54, 191-197. http://dx.doi.org/10.1016/0006-3002(61)90387-0

Blokhina, O., Virolainen, E., \& Fagerstedt, K. V. (2003). Antioxidants, oxidative damage and oxygen deprivation stress: a review. Annals of Botany, 91, 179-194. http://dx.doi.org/10.1093/aob/mcf118

Boker, L. K., Van der Schouw, Y. T., De Kleijn, M. J., Jacques, P. F., Grobbee, D. E., \& Peeters, P. H. (2002). Intake of dietary phytoestrogens by Dutch women. Journal of Nutrition, 132, 1319-1328.

Booth, I. W., Aukett, M. A. (1997). Iron deficiency anaemia in infancy and early childhood. Archives of Diseases of Childhood, 76, 549-553. http://dx.doi.org/10.1136/adc.76.6.549

Bowman, D. E. (1944). Fractions derived from soya beans and navy beans which retard tryptic digestion of casein Proceedings of the Society of Experimental Biology and Medicine, 57, 139. http://dx.doi.org/10.3181/00379727-57-14731P

Bowman, D. E. (1946). Differentiation of soybean antitryptic factors Proceedings of the Society of Experimental Biology and Medicine, 63, 547-550. http://dx.doi.org/10.3181/00379727-63-15668

Bridle, P., \& Timberlake, C. F. (1997). Anthocyanins as natural food colours - selected aspects. Food Chemistry, 58, 103-109. http://dx.doi.org/10.1016/S0308-8146(96)00222-1

Burtis, E. L. (1950). World soybean production and trade. In K. S. Markley (Ed.). Soybeans and Soybean Products. (Vol. I, pp. 61-108), New York: Inc. Interscience Publishers.

Chen, Y. M., Ho, S. C., Lam, S. S., Ho, S. S., \& Woo, J. L. (2004). Beneficial effect of soy isoflavones on bone mineral content was modified by years since menopause, body weight, and calcium intake: a double-blind, $\begin{array}{lllll}\text { randomized, } & \text { controlled } & \text { Menopause, } & \text { 246-254. }\end{array}$ http://dx.doi.org/10.1097/01.GME.0000094394.59028.46

Choung, M. G., Baek, I. Y., Kang, S. T., Han, W. Y., Shin, D. C., Moon, H. P., \& Kang, K. H. (2001). Isolation and determination of anthocyanins in seed coats of black soybean (Glycine max (L.) merr.) Journal of Agricultural and Food Chemistry, 49, 5848-5851. http://dx.doi.org/10.1021/jf010550w

Chung, I. M. (1998). Test of antioxidative activity on Korean native black soybean. Daesan Nonchong, 6, 23-30.

Codina, R., Arduso, L., Lockney, R. F., Crisci, C., \& Medina, I. (2003). Allergenicity of varieties of soybean. Allergy, 58, 1293-1298. http://dx.doi.org/10.1046/j.1398-9995.2003.00301.x

Cole, J. T., Fahey, G. C., Merchen, R., Patil, A. R., Murray, S. M., Hussein, H. S., \& Brent, J. L. (1999). Soybean hulls as a dietary fiber source for dogs. Journal of Animal Science, 77, 917-924.

Corner, E. J. H. (1951). The leguminous seed. Phytomorphology, 1, 117-150.

de Kleijn, M. J., van der Schouw, Y. T., Wilson, P. W., Adlercreutz, H., Mazur, W., Grobbee, D. E., \& Jacques, P. F. (2001). Intake of dietary phytoestrogens is low in postmenopausal women in the United States: the Framingham study. Journal of Nutrition, 131, 1826-1832.

Dinsdale, E. C., \& Ward, W. E. (2010). Exposure to soy isoflavones and effects on reproductive health: A review of human and animal studies. Nutrients, 2, 1156-1187. http://dx.doi.org/10.3390/nu2111156 
Eldridge, A. C., \& Kwolek, W. F. (1983). Soybean isoflavones: effect of environment and variety on composition. Journal of Agricultural and Food Chemistry, 31, 394-396. http://dx.doi.org/10.1021/jf00116a052

Fiorini, M. (1995). Preparative high-perfomance liquid chromatography for the purification of natural $\begin{array}{lllll}\text { anthocyanins. Journal of } & \text { Chromatography }\end{array}$ http://dx.doi.org/10.1016/0021-9673(94)01020-F

Fournier, D. B., Erdman, J. W., Jr., \& Gordon, G. B. (1998). Soy, its components, and cancer prevention: a review of the in vitro, animal, and human data. Cancer Epidemiology and Biomarkers Prevention, 7, 1055-1065.

Frankel, W. L., Choe, D. M., Zhang, W., Roth, J. A., Don, S. H., Afonso, J. J., ... Rombeau, J. L. (1994). Soy fiber delays disease onset and prolongs survival in experimental Clostridium difficile ileocecitis. Journal of Parenteral and Enteral Nutrition, 18, 55-61. http://dx.doi.org/0.1177/014860719401800155

Garcia, M. C., Torre, M., Marina, M. L., \& Laborda, F. (1997). Composition and characterization of soyabean and related products. Critical Reviews in Food Science and Nutrition, 37, 361-391. http://dx.doi.org/10.1080/10408399709527779

Gizjen, M., van Huystee, R., \& Buzzell, R. I. (1993). Soybean seed coat peroxidase. A comparison of high-activity and low-activity genotypes. Plant Physiology, 103, 1061-1066.

Golbitz, P. (2010). Global soy and soy products. ASAIM 3rd Soy Symposium Program. August 2, 2010, Sheraton Surabaya Hotel, Surabaya, Indonesia.

Gran, B., Tabibzadeh, N., Martin, A., Ventura, E. S., Ware, J. H., Zhang, G. X., ... Rostami, A. M. (2006). The protease inhibitor, Bowman-Birk Inhibitor, suppresses experimental autoimmune encephalomyelitis: A potential oral therapy for multiple sclerosis Multiple Sclerosis, 12, 688-697. http://dx.doi.org/10.1177/1352458506070769

Grassmann, J., Hippeli, S., \& Elstner, E. F. (2002). Plant's defence and its benefits for animals and medicine: role of phenolics and terpenoids in avoiding oxygen stress. Plant Physiology and Biochemistry, 40, 471-478. http://dx.doi.org/10.1016/S0981-9428(02)01395-5

Habauzit, V., \& Morand, C. (2011). Evidence for a protective effect of polyphenols-containing foods on cardiovascular health: An update for clinicians. Therapeutic Advances in Chronic Disease, 3, 87-106. http://dx.doi.org/10.1177/2040622311430006

Horn-Ross, P. L., Barnes, S., Lee, M., Coward, L., Mandel, J. E., Koo, J., ... Smith, M. (2000a). Assessing phytoestrogen exposure in epidemiological studies: development of a database (United States). Cancer Causes and Control, 11, 289-298. http://dx.doi.org/10.1023/A:1008995606699

Horn-Ross, P. L., Lee, M., John, E. M., \& Koo, J. (2000b). Sources of phytoestrogen exposure among non-Asian women in California, USA. Cancer Causes and Control, 11, 299-302. http://dx.doi.org/10.1023/A:1008968003575

INACG (International Nutritional Anemia Consultative Group). (1998). Guidelines for the use of iron supplements to prevent and treat iron deficiency anemia. Washington, DC: ILSI Press http://www.who.int/nutrition/publications/micronutrients/anaemia_iron_deficiency/1-57881-020-5/en/

Isanga, J., \& Zhang, G. N. (2008). Soybean bioactive components and their implications to health - A review. Food Reviews International, 24, 252-276. http://dx.doi.org/10.1080/87559120801926351

Ishii, Y., \& Tanizawa, H. (2006). Effects of soyasaponins on lipid peroxidation through the secretion of thyroid hormones. Biological and Pharmaceutical Bulletin, 29, 1759-1763. http://dx.doi.org/10.1248/bpb.29.1759

Jacob, R. A., Sandstead, H. H., Klevay, L.M., \& Johnson, L. K. (1980). Utility of serum ferritin as a measure of iron deficiency in normal males undergoing repetitive phlebotomy. Blood, 56, 786-791.

Jan, G., Belzacq, A. S., Haouzi, D., Rouault, A., Metivier, D., Kroemer, G., \& Brenner, C. (2002). Propionibacteria induce apoptosis of colorectal carcinoma cells via short-chain fatty acids acting on mitochondria. Cell Death Differentiation, 9, 179-188. http://dx.doi.org/10.1038/sj.cdd.4400935

Jenkins, D. J. A. (1988). Carbohydrates (B) dietary fiber. In M. E. Shils \& V. R. Young (Eds.), Modern nutrition in health and disease (7th ed.) (pp. 2-71). Philadelphia: Lea and Febiger.

Jin, M., Yang, Y., Su, B., \& Ren, Q. (2006). Rapid quantification and characterization of soyasaponins by high-performance liquid chromatography coupled with electrospray mass spectrometry. Journal of 
Chromatography A, 1108, 31-37. http://dx.doi.org/10.1016/j.chroma.2005.12.099

Johnson, C. D., Berry, M. F., \& Weaver, C. M. (1985). Soybean hulls as an iron source for bread enrichment. Journal of Food Science, 50, 1275-1277, 1305. http://dx.doi.org/10.1111/j.1365-2621.1985.tb10460.x

Kamal, J. K. A., \& Behere, D. V. (2002). Thermal and conformational stability of seed coat soybean peroxidase. Biochemistry, 41, 9034-9042. http://dx.doi.org/10.1021/bi025621e

Kanamoto, Y., Yamashita, Y., Nanba, F., Yoshida, T., Tsuda, T., Fukuda, I., ... Ashida, H. (2011). A black soybean seed coat extract prevents obesity and glucose intolerance by up-regulating uncoupling proteins and down-regulating inflammatory cytokines in high-fat diet-fed mice. Journal of Agricultural and Food Chemistry, 59, 8985-8993. http://dx.doi.org/10.1021/jf201471p

Keinan Boker, L., van der Schouw, Y. T., de Kleijn, M. J. J., Jacques, P. F., Grobbee, D. E., \& Peeters, P. H. M. (2002). Intake of dietary phytoestrogens in Dutch women. Journal of Nutrition, 132, 1319-1328.

Kennedy, A. R. (1998). Chemopreventive agents: protease inhibitors Pharmacological Therapy, 78, 167-209. http://dx.doi.org/10.1016/S0163-7258(98)00010-2

Kennedy, A. R., Beazer-Barclay, Y., Kinzler, K. W., \& Newbern, P. M. (1996). Suppression of carcinogenesis in the intestines of min mice by the soybean-derived Bowman-Birk inhibitor Cancer Research, 56, 679-682.

Kenny, A. M., Mangano, K. M., Abourizk, R. H., Bruno, R. S., Anamani, D. E., Kleppinger, A., ... Kerstetter, J. E. (2009). Soy proteins and isoflavones affect bone mineral density in older women: a randomized controlled trial. American Journal of Clinical Nutrition, 90, 234-242. http://dx.doi.org/10.3945/ajen.2009.27600

Kerwin, S. M. (2004). Soy saponins and the anticancer effects of soybeans and soy-based foods. Current Medicinal and Chemical Anticancer Agents, 4, 263-272. http://dx.doi.org/10.2174/1568011043352993

Kim, J. M., Kim, J. S., Yoo, H., Choung, M. G., \& Sung, M. K. (2008). Effects of black soybean [Glycine max (L.) Merr.] seed coats and its anthocyanidins on colonic inflammation and cell proliferation in vitro and in vivo. Journal of Agricultural and Food Chemistry, 56, 8427-8433. http://dx.doi.org/10.1021/jf801342p

Kim, H. J., Tsoy, I., Park, J. M., Chung, J. I., Shin, S. C., \& Chang, K. C. (2006). Anthocyanins from soybean seed coat inhibit the expression of TNF-alpha-induced genes associated with ischemia/reperfusion in endothelial cell by NF-kappaB-dependent pathway and reduce rat myocardial damages incurred by ischemia and reperfusion in vivo. FEBS Letters, 580, 1391-1397. http://dx.doi.org/10.1016/j.febslet.2006.01.062

Kushwaha, K., O’Bryan, C. A., Babu, D., Crandall, P. G., Chen, O., \& Lee, S. O. (2014). Human health effects of isoflavones from soybeans. Agriculture, Food and Analytical Bacteriology, 4, 122-142.

Kwon, S. H., Ahn, I. S., Kim, S. O., Kong, C. S., Chung, H. Y., Do, M. S., \& Park, K. Y. (2007). Anti-obesity and hypolipidemic effects of black soybean anthocyanins. Journal of Medicinal Food, 10, 552-556. http://dx.doi.org/10.1089/jmf.2006.147

Lee, J. H., Kang, N. S., Shin, S. O., Shin, S. H., Lim, S. G., Suh, D. Y., ... Ha, T. J. (2009). Characterisation of anthocyanins in the black soybean (Glycine max L.) by HPLC-DAD-ESI/MS analysis. Food Chemistry, 112, 226-231. http://dx.doi.org/10.1016/j.foodchem.2008.05.056

Lee, S. O., Simons, A. L., Murphy, P. A., \& Hendrich, S. (2005). Soyasaponins lowered plasma cholesterol and increased fecal bile acids in female golden Syrian hamsters. Experimental Biology and Medicine, 230, 472-478.

Lehrfeld, J. (1989). High-performance liquid-chromatography analysis of phytic acid on a pH stable, macroporous polymer column. Cereal Chemistry, 66, 510-515.

Levine, S. E., Weaver, C. M., \& Kirleis, A. W. (1982). Accumulation of selected trace elements in hydroponically grown soy-beans and distribution of the elements in processed soybean fractions. Journal of Food Science, 47, 1283-1287. http://dx.doi.org/10.1111/j.1365-2621.1982.tb07667.x

Ley, R. D., Applegate, L. A., Fry, R. J. M., \& Sanchez, A. B. (1991). Photoreactivation of ultraviolet radiation-induced skin and eye tumors of Monodelphis domestica. Cancer Research, 51, 6539-6542.

Lichtenstein, G. R., Deren, J., Katz, S., Lewis, J. D., Kennedy, A. R., \& Ware, J. H. (2008). Bowman-Birk Inhibitor concentrate: a novel therapeutic agent for patients with active ulcerative colitis. Digestive Diseases and Sciences, 53, 175-180. http://dx.doi.org/10.1007/s10620-007-9840-2 
Lindstrom, J. T., \& Vodkin, L. O. (1991). A soybean cell-wall protein is affected by seed color genotype. Plant Cell, 3, 561-571. http://dx.doi.org/10.2307/3869185

Liu, K. S. (1997). Agronomic characteristics, production and marketing. Chapter 1. In K. Liu, (Ed.). In Soybeans: Chemistry, Technology and Utilization. (pp. 1-24): New York, NY: Chapman \& Hall. http://dx.doi.org/10.1007/978-1-4615-1763-4_1

Lolas, G. M., Palamidis, N., \& Markakis, P. (1976). Phytic acid total phosphorous relationship in barley, oats, soybeans and wheat. Cereal Chemistry, 53, 867-871.

Losso, J. N., Munene, C. N., Bansode, R. R., \& Bawadi, H. (2004). Inhibition of matrix metalloproteinase-1 activity by the soybean Bowman-Birk inhibitor. Biotechnology Letters, 26, 901-905. http://dx.doi.org/10.1023/B:bile.0000025900.33812.7c

Lui, K. (2004). Fermented Soy Foods: Overview. Handbook of Food and Beverage Fermentation Technology. New York: Marcel Dekker, Inc.

Lykken, G. I., Mahalko, J. R., Nielsen, E. J., \& Dintzis, F. R. (1987). Availability of soybean hull iron to humans. Journal of Food Science, 52, 1545-1548. http://dx.doi.org/10.1111/j.1365-2621.1987.tb05876.x

Lynch, S. R., Beard, J. L., Dassenko, S. A., \& Cook, J. D. (1984). Iron absorption from legumes in humans. American Journal of Clinical Nutrition, 40, 42-49.

Malenčić, D., Popović, M., \& Miladinović, J. (2007). Phenolic content and antioxidant properties of soybean (Glycine max (L.) Merr.) seeds. Molecules, 12, 576-581. http://dx.doi.org/10.3390/12030576

Malkowicz, S. B., McKenna, W. G., Vaughn, D. J., Wan, X. S., Propert, K. J., Rockwell, K., ... Kennedy, A. R. (2001). Effects of Bowman-Birk Inhibitor Concentrate (BBIC) in patients with benign prostatic hyperplasia. Prostate, 48, 16-28. http://dx.doi.org/10.1002/pros.1077

Martino, H. S., Carvalho, A. W., Silva, C. O., Dantas, M. I., Natal, D. I., Ribeiro, S. M., \& Costa, N. M. (2011). Heat-treated hull flour does not affect iron bioavailability in rats. Archivos Latinoamericanos de Nutricion, 61, 135-142.

Masuda, T., \& Goldsmith, P. D. (2009). World soybean production: area harvested, yield, and long-term projections. International Food and Agribusiness Management Review, 12, 143-162.

Matsui, M. S., \& Deleo, V. A. (1991). Longwave ultraviolet radiation and promotion of skin cancer. Cancer Cells-A Monthly Review, 3, 8-12.

Mazza, G., \& Miniati, E. (1993). Legumes. In Anthocyanins in Fruits, Vegetables, and Grains (pp. 254-255). Boca Raton, FL: Inc. CRC Press.

Messina, M., \& Barnes, S. (1991). The role of soy products in reducing risk of cancer. Journal of the National Cancer Institute, 83, 541-546. http://dx.doi.org/10.1093/jnci/83.8.541

Miller S. S., Bowman, L. A., Gizen, M., \& Miki, B. L. A. (1999). Early development of the seed coat of soybean (Glycine max). Annals of Botany, 84, 297-304. http://dx.doi.org/10.1006/anbo.1999.0915

Muricken, D. G., \& Gowda, L. R. (2011). Molecular engineering of a small trypsin inhibitor based on the binding loop of horsegram seed Bowman-Birk inhibitor Journal of Enzyme Inhibition and Medical Chemistry, 26, 553-560. http://dx.doi.org/10.3109/14756366.2010.536158

Murray, D. R. (1979). Nutritive role of the seed coats during embryo development in Pisum sativum L. Plant Physiology, 64, 763-769. http://dx.doi.org/10.1104/pp.64.5.763

Murray-Kolb, L. E., Welch, R., Theil, E. C., \& Beard, J. L. (2003). Women with low iron stores absorb iron from soybeans. American Journal of Clinical Nutrition, 77, 180-184.

Nizamutdinova, I. T., Jin, Y. C., Chung, J. I., Shin, S. C., Lee, S. J., Seo, H. G., ... Kim, H. J. (2009). The anti-diabetic effect of anthocyanins in streptozotocin-induced diabetic rats through glucose transporter 4 regulation and prevention of insulin resistance and pancreatic apoptosis. Molecular Nutrition and Food Research, 53, 1419-1429. http://dx.doi.org/10.1002/mnfr.200800526

Oba, M., \& Allen, M. S. (2003). Effects of corn grain conservation method on feeding behavior and productivity of lactating dairy cows at two dietary starch concentration. Journal of Dairy Science, 86, 174-183. http://dx.doi.org/10.3168/jds.S0022-0302(03)73598-X

Omoni, A. O., \& Aluko, R. E. (2005). Soybean foods and their benefits: Potential mechanisms of action. Nutriton Reviews, 63, 272-283. http://dx.doi.org/10.1301/nr.2005.aug.272-283. 
Openshaw, S. J., \& Hadley, H. H. (1978). Maternal effects on sugar content in soybean seeds. Crop Science, 18 , 581-584. http://dx.doi.org/10.2135/cropsci1978.0011183X001800040014x

Paik, S. S., Jeong, E., Jung, S. W., Ha, T. J., Kang, S., Sim, S.,... Kim, I. B. (2012). Anthocyanins from the seed coat of black soybean reduce retinal degeneration induced by N-methyl-N-nitrosourea. Experimental Eye Research, 97, 55-62. http://dx.doi.org/10.1016/j.exer.2012.02.010

Petri, G., Krawczyk, U., \& Kery, Á. (1997). Spectrophotometric and chromatographic investigation of bilberry anthocyanins for quantification purposes. Microchemical Journal, 55, 12-23. http://dx.doi.org/10.1006/mchj.1996.1349

Philbrick, D. J., Bureau, D. P., Collins, F. W., \& Holub, B. J. (2003). Evidence that soyasaponin Bb retards disease progression in a murine model of polycystic kidney disease. Kidney Internatinal, 63, 1230-1239. http://dx.doi.org/10.1046/j.1523-1755.2003.00869.x

Phommalth, S., Jeong, Y. S., Kim, Y. H., Dhakal, K. H., \& Hwang, Y. H. (2008). Effects of light treatment on isoflavone content of germinated soybean seeds. Journal of Agricultural and Food Chemistry, 56. http://dx.doi.org/10.1021/jf802118g

Raboy, V., \& Dickinson, D. B. (1984). Effect of phosphorous and zinc nutrition on soybean phytic acid and zinc. Plant Physiology, 75, 1094-1098. http://dx.doi.org/10.1104/pp.75.4.1094

Renault, J. H., Thépenier, P., Zéches-Hanrot, M., Men-Olivier, L. L., Durand, A., Foucault, A., \& Margraff, R. (1997). Preparative separation of anthocyanins by gradient elution centrifugal partition chromatography. Journal of Chromatography A, 763, 345-352. http://dx.doi.org/10.1016/S0021-9673(96)00880-1

Ronis, M. J., Chen, Y., Badeaux, J., \& Badger, T. M. (2009). Dietary soy protein isolate attenuates metabolic syndrome in rats via effects on PPAR, LXR and SREBP signaling. Journal of Nutrition, 139, 1431-1438. http://dx.doi.org/10.3945/jn.109.107029

Ryan, B. J., Carolan, N., \& O'Fagain, C. (2006). Horseradish and soybean peroxidases: Comparable tools for alternative niches? Trends in Biotechnology, 24, 355-363. http://dx.doi.org/10.1016/j.tibtech.2006.06.007

Safavi, F., \& Rostami, A. (2012). Role of serine proteases in inflammation: Bowman-Birk protease inhibitor (BBI) as a potential therapy for autoimmune diseases. Experimental and Molecular Pathology, 93(SI), 428-433. http://dx.doi.org/10.1016/j.yexmp.2012.09.014

Scheppach, W., Bartram, H. P., \& Richter, F. (1995). Role of short-chain fatty acids in the prevention of colorectal cancer. European Journal of Cancer, 31A, 1077-1080. http://dx.doi.org/10.1016/0959-8049(95)00165-F

Sessa, D. J. (2004). Processing of soybean hulls to enhance the distribution and extraction of value-added proteins. Journal of the Science of Food and Agriculture, 84, 75-82. http://dx.doi.org/10.1002/jsfa.1612

Sessa, D. J., \& Wolf, W. J. (2001). Bowman Birk inhibitors in soybean seed coats. Industrial Crops and Products, 14, 73-83. http://dx.doi.org/10.1016/S0926-6690(00)00090-X

Shames, B. D., Barton, H. H., Reznikov, L. L., Cairns, C. B., Banerjee, A., Harken, A. H., \& Meng, X. (2002). Ischemia alone is sufficient to induce TNF-alpha mRNA and peptide in the myocardium. Shock, 17, 114-119. http://dx.doi.org/10.1097/00024382-200202000-00006

Shaw, J. G., \& Friedman, J. F. (2011). Iron deficiency anemia: focus on infectious diseases in lesser developed countries. Anemia, 260380. http://dx.doi.org/10.1155/2011/260380

Shurtleff, W., \& Aoyagi, A. (2007). History of world soybean production and trade-part 1. Retrieved from http://www.soyinfocenter.com/HSS/production_and_trade1.php

Stafford, A. (1978). Aspects of development of the cotyledon and testa of Pisum sativum. PhD Thesis. East Anglia University, Norwich, England.

Sutardi, \& Buckle, K. A. (1985). Phytic acid changes in soybeans fermented by traditional inoculum and 6 strains of Rhizopus oligosporus. Journal of Applied Bacteriology, 58, 539-543. http://dx.doi.org/10.1111/j.1365-2672.1985.tb01709.x

Titgemeyer, E. C., Bourquin, L. D., Fahey, G. C., \& Garleb, K. A. (1991). Fermentability of various fiber sources by human fecal bacteria in vitro. American Journal of Clinical Nutrition, 53, 1418-1424.

Todd, J. J., \& Vodkin, L. O. (1993). Pigmented soybean (Glycine max) seed coats accumulate proanthocyanidins during development. Plant Physiology, 102, 663-670. 
Torres, N., Torre-Villalvazo, I., \& Tovar, A. R. (2006). Regulation of lipid metabolism by soy protein and its implication in diseases mediated by lipid disorders. Journal of Nutritional Biochemistry, 17, 365-73. http://dx.doi.org/10.1016/j.jnutbio.2005.11.005

Tsoyi, K., Bin Park, H., Kim, Y. M., Il Chung, J., Shin, S. C., Lee, W. S., ... Kim, H. J. (2008). Anthocyanins from black soybean seed coats inhibit UVB-induced inflammatory cylooxygenase-2 gene expression and $\mathrm{PGE}(2)$ production through regulation of the nuclear factor-kappa B and phosphatidylinositol 3-kinase/Akt pathway. Journal of Agricultural and Food Chemistry, 56, 8969-8974. http://dx.doi.org/10.1021/jf801345c

Uberoi, S. K., Vadhera, S., \& Soni, G. L. (1992). Role of dietary fiber from pulses and cereals as hypocholesterolemic and hypolipidemic agent. Journal of Food Science and Technology-Mysore, 29, 281-283.

van Erp-Baart, M. A., Brants, H. A., Kiely, M., Mulligan, A., Turrini, A., Sermoneta, C., ... Valsta, L. M. (2003). Isoflavone intake in four different European countries: the VENUS approach. British Journal of Nutrition, 89 Suppl 1, S25-S30. http://dx.doi.org/10.1079/BJN2002793

Vierling, R. A., \& Wilcox, J. R. (1996). Microplate assay for soybean seed coat peroxidase activity. Seed Science and Technology, 24, 485-494.

Vincieri, F. F., Romani, A., Baldi, A., Mulinacci, N., \& Alberti, M. B. (1992). Analysis HPLC of anthocyanins present in fluid extracts from Malva sylvestris L. flowers and leaves. Bulletin of the Liaison-Groupe Polyphenols, 16, 339-342.

Wang, H. J., \& Murphy, P. A. (1994). Isoflavone composition of American and Japanese soybeans in Iowa effects of variety, crop year and location. Journal of Agricultural and Food Chemistry, 42, 1674-1677. http://dx.doi.org/10.1021/jf00044a017

Waterhouse, A. L. (1995). Wine and heart disease. Chemical Industry May 1, 1995, 338-341.

Weaver, C. M., Nelson, N., \& Elliott, J. G. (1984). Bioavailability of iron to rats from processed soybean fractions determined by intrinsic and extrinsic labeling techniques. Journal of Nutrition, 114, 1042-1048.

Welch, R. M., \& Van Campen, D. R. (1975). Iron availability to rats from sovbeans. Journal of Nutrition, 105, 253-256.

Wolf, W. J. (1970). Soybean proteins: their functional, chemical, and physical properties. Journal of Agricultural and Food Chemistry, 18, 969-976. http://dx.doi.org/10.1021/jf60172a025

Wright, H., \& Nicell, J. A. (1999). Characterization of soybean peroxidase for the treatment of aqueous phenols. Bioresource Technology, 70, 69-79. http://dx.doi.org/10.1016/S0960-8524(99)00007-3

Ximenes, H., Hirata, A., Rocha, M., Curi, R., \& Carpinelli, A. (2007). Propionate inhibits glucose-induced insulin secretion in isolated rat pancreatic islets. Cell Biochemistry and Function, 25, 173-178. http://dx.doi.org/10.1002/cbf.1297

Xu, B., \& Chang, S. K. (2008). Antioxidant capacity of seed coat, dehulled bean, and whole black soybeans in relation to their distributions of total phenolics, phenolic acids, anthocyanins, and isoflavones. Journal of Agriculture and Food Chemistry, 56, 8365-73. http://dx.doi.org/10.1021/jf801196d

Yoshikoshi, M., Yoshiki, Y., Okubo, K., Seto, J., \& Sasaki, Y. (1996). Prevention of hydrogen peroxide damage by soybean saponins to mouse fibroblasts Planta Medica, 62, 252-255. http://dx.doi.org/10.1055/s-2006-957871

Young, V. R. (1991). Soy protein in relation to human protein and amino acid nutrition. Journal of the American Dietetic Association, 91, 828-835.

Yue, X. H., Abdallah, A. M., \& Xu, Z. M. (2010). Distribution of isoflavones and antioxidant activities of soybean cotyledon, coat and germ. Journal of Food Processing and Preservation, 34, 795-806. http://dx.doi.org/10.1111/j.1745-4549.2009.00395.x

Zarkadas, C. G., Yu, Z., \& Voldeng, H. D. (1993). Minero-Amador, A. Assessment of the protein quality of a new high-protein soybean cultivar by amino acid analysis. Journal of Agricultural and Food Chemistry, 41, 616-623. http://dx.doi.org/10.1021/jf00028a021

Zhan, S., \& Ho, S. C. (2005). Meta-analysis of the effects of soy protein containing isoflavones on the lipid profile. American Journal of Clinical Nutrition, 81, 397-408.

Zhang, R. F., Zhang, F. X., Zhang, M. W., Wei, Z. C., Yang, C. Y., Zhang, Y.,... Chi, J. W. (2011). Phenolic 
composition and antioxidant activity in seed coats of 60 Chinese black soybean (Glycine max L. Merr.) varieties. Journal of Agricultural and Food Chemistry, 59, 5935-5944. http://dx.doi.org/10.1021/jf201593n

Zhou, J., Martin, R., Tulley, R., Raggio, A. M., McCutcheon, K. L., Shen, L., ... Keenan, M. J. (2008). Dietary resistant starch upregulates total GLP-1 and PYY in a sustained day-long manner through fermentation in rodents. American Journal of Physiology and Endocrinology Metabolism, 295, E1160-E1166. http://dx.doi.org/10.1152/ajpendo.90637.2008

\section{Copyrights}

Copyright for this article is retained by the author(s), with first publication rights granted to the journal.

This is an open-access article distributed under the terms and conditions of the Creative Commons Attribution license (http://creativecommons.org/licenses/by/3.0/). 